\title{
Glacio-lacustrine aragonite deposition, meltwater evolution and glacial history during isotope stage 3 at Radok Lake, Amery Oasis, northern Prince Charles Mountains, East Antarctica
}

\author{
IAN D. GOODWIN ${ }^{1}$ and JOHN HELLSTROM ${ }^{2}$ \\ ${ }^{1}$ Environmental and Climate Change Research Group, School of Environmental and Life Sciences, University of Newcastle, Callaghan, \\ NSW 2308, Australia \\ ${ }^{2}$ School of Earth Sciences, University of Melbourne, Parkville, VIC 3010, Australia \\ Ian.Goodwin@newcastle.edu.au
}

\begin{abstract}
The late Quaternary glacial history of the Amery Oasis, and Prince Charles Mountains is of significant interest because about $10 \%$ of the total modern Antarctic ice outflow is discharged via the adjacent Lambert Glacier system. A glacial thrust moraine sequence deposited along the northern shoreline of Radok Lake between 20-10 ka BP, overlies a layer of thin, aragonite crusts which provide important constraints on the glacial history of the Amery Oasis. The modern Radok Lake is fed by the terminal meltwaters of the alpine Battye Glacier. The aragonite crusts were deposited in shallow water of ancestral Radok Lake $53 \mathrm{ka}$ BP, during the A3 warm event in Isotope Stage 3. Oxygen isotope $\left(\delta^{18} \mathrm{O}\right)$ analysis of the last glacial-age aragonite crusts indicates that they precipitated from freshwater with a $\delta^{18} \mathrm{O}_{\text {SMOW }}$ composition of $-36 \%$, which is $8 \%$ more depleted than the present water $(-28 \%)$ in Radok Lake. A regional oxygen isotope $\left(\delta^{18} \mathrm{O}\right)$ and elevation relationship for snow is used to determine the source of meltwater and glacial ice in Radok Lake during the A3 warm event. This relationship indicates that Radok Lake received meltwater from the confluence of both Battye Glacier ice and an expansion of grounded western Lambert Glacier ice in the Amery embayment.
\end{abstract}

Received 31 July 2006, accepted 8 November 2006, first published online 29 June 2007

Key words: carbonate, glacial meltwater, lacustrine, Lambert Glacier grounding, oxygen isotope

\section{Introduction}

Radok Lake is a large, glacial lake $\left(20 \mathrm{~km}^{2}\right.$ in area $)$ in the Amery Oasis of the Northern Prince Charles Mountains (Bardin et al. 1990) (Figs 1 \& 2). The water level in the modern lake lies $7 \mathrm{~m}$ above sea level and the nearby, tidal Beaver Lake which is an epishelf lake formed in an embayment adjacent to the Amery Ice Shelf (Adamson et al. 1997). The modern Radok Lake lies in an overdeepened basin that is up to $346 \mathrm{~m}$ deep (339 m below modern sea level), and is surrounded by rock cliffs up to $400 \mathrm{~m}$ above the lake surface (Fig. 3). The lake is presently fed by glacial meltwater from the small Battye Glacier (13 km long) which drains the local ice plateau of the McLeod Massif (Fig. 4). Radok Lake overflows at times of peak meltwater inflow, and drains to Pagodroma Gorge and Beaver Lake, via a shallow sill, at the eastern edge of the lake.

Adamson et al. (1997) mapped the present and former shoreline geomorphology of Radok Lake and reported a glacial thrust moraine sequence at an elevation of $\sim 50-80 \mathrm{~m}$ (after McKelvey et al. 1995, 2001) and mapped a raised shoreline at $\sim 70-80 \mathrm{~m}$ above the present northern shoreline of Radok Lake. They suggested a Holocene age for the thrust moraines based on their relatively recent weathering, when compared to the surrounding sediments. Subsequently, cosmogenic surface dating using ${ }^{10} \mathrm{Be}$ and ${ }^{26} \mathrm{Al}$ isotopes by Fink et al. (2006) has established the pattern of glacial retreat from the northern shore of Radok Lake basin. Grounded ice retreated from a position at $125 \mathrm{~m}$ elevation on the slope above the northern Radok Lake shoreline at $20.0 \mathrm{ka} \pm$ $2.2 \mathrm{ka}$, to a position at $70 \mathrm{~m}$ elevation, close to the thrust moraine sequence by $10.5 \pm 1 \mathrm{ka}$. On the basis of these paired cosmogenic surface exposure ages, Fink et al. (2006) confirmed that the thrust moraine sequence was deposited during the Late Glacial-Holocene transition, as a result of the shrinking of the glacial-age Battye Glacier.

The fabric of the sediments in the moraine (M. Hambrey, personal communication 1999) and the pattern of surface exposure indicate that the moraine was deposited by ice flowing from Radok Lake onto the northern slope. However, it is unknown whether the ice in Radok Lake during the last glacial cycle originated from an alpine catchment in the northern Prince Charles Mountains or whether it originated from a Lambert Glacier ice stream overriding the Amery Oasis. The latter would require a substantial thickening and grounding zone advance of the Amery Ice Shelf-Lambert Glacier system to at least the locality of the Amery Oasis, which is $200-300 \mathrm{~km}$ inland from the ice shelf front in Prydz Bay. The modern Lambert Glacier Amery Ice Shelf grounding zone is located approximately $200 \mathrm{~km}$ further inland (Fricker et al. 2002). Adamson et al. (1997) reported that glacial and fluvial landforms, degree of surface and 


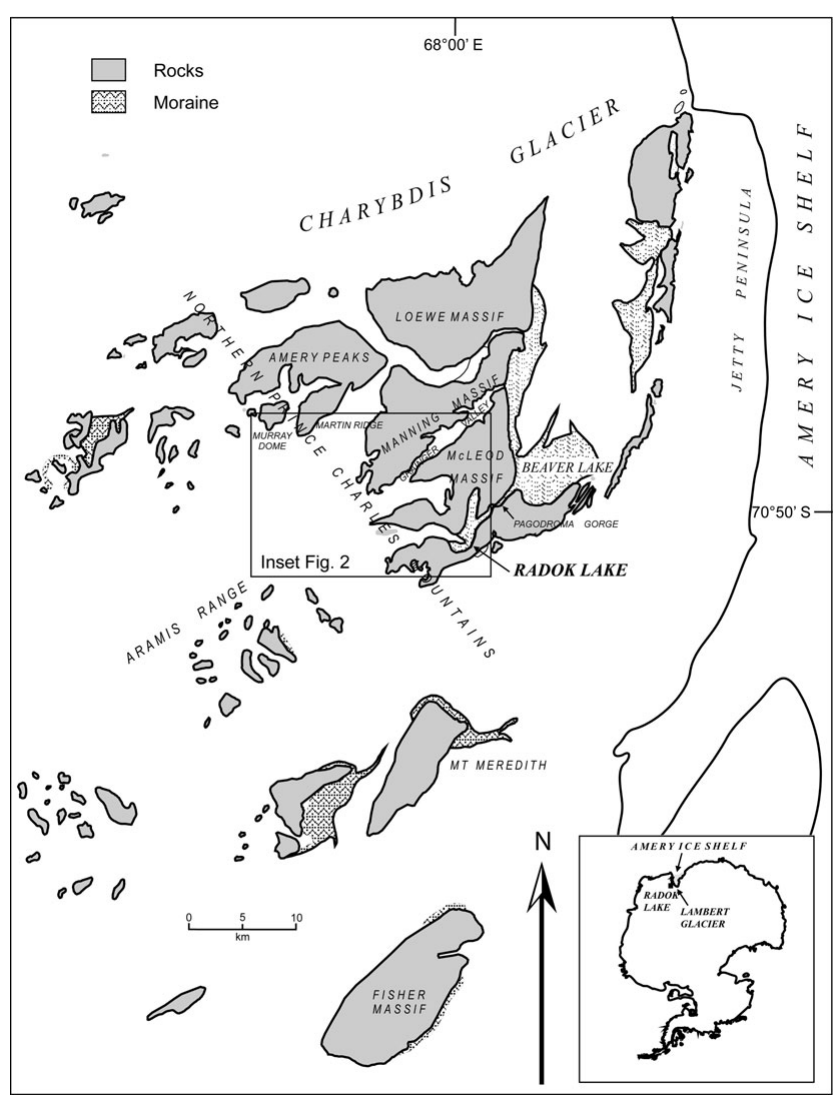

Fig. 1. Location map showing the Amery Oasis, northern Prince Charles Mountains, Amery Ice Shelf and Lambert Glacier system.

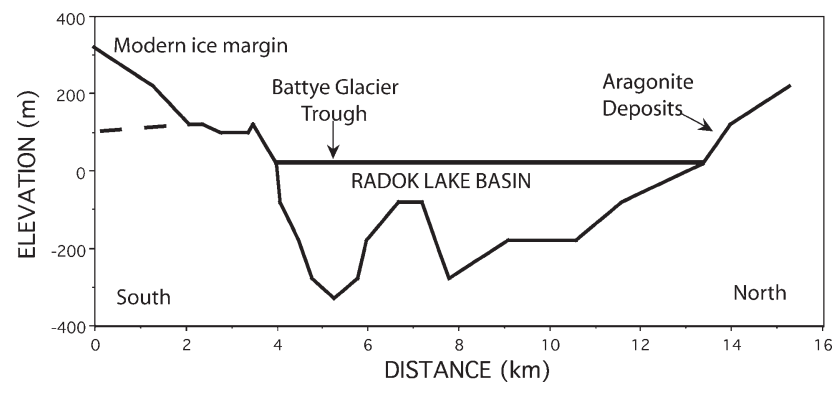

Fig. 3. Topographic cross section through the Radok Lake basin from the Jetty Peninsula ice ridge in the south to the northern basin slopes.

sediment weathering and the presence of surface sediments rich in Pliocene fauna indicated that the Radok Lake basin and Amery Oasis had not been overridden by Lambert Glacier ice streams since the Pliocene.

On the north-eastern corner of Radok Lake, a modern melt-stream has incised into the surface sediments and has cut a number of braided channels down to the modern Radok Lake shoreline. A conspicuous feature in the main channel (Fig. 5) is an outcrop of carbonate crusts. This outcrop is located $\sim 10-20$ m elevation above most of the thrust moraine sediments. These carbonate crusts were sampled in the 1988/89 summer field season for isotope geochemistry analysis, to provide an insight into their origin and possible evolution of meltwater in the Radok Lake basin, and the associated glacial history of the Amery Oasis. The characteristics of the carbonates and their isotope geochemistry are discussed below, together with the glacial history of the Radok Lake catchment.

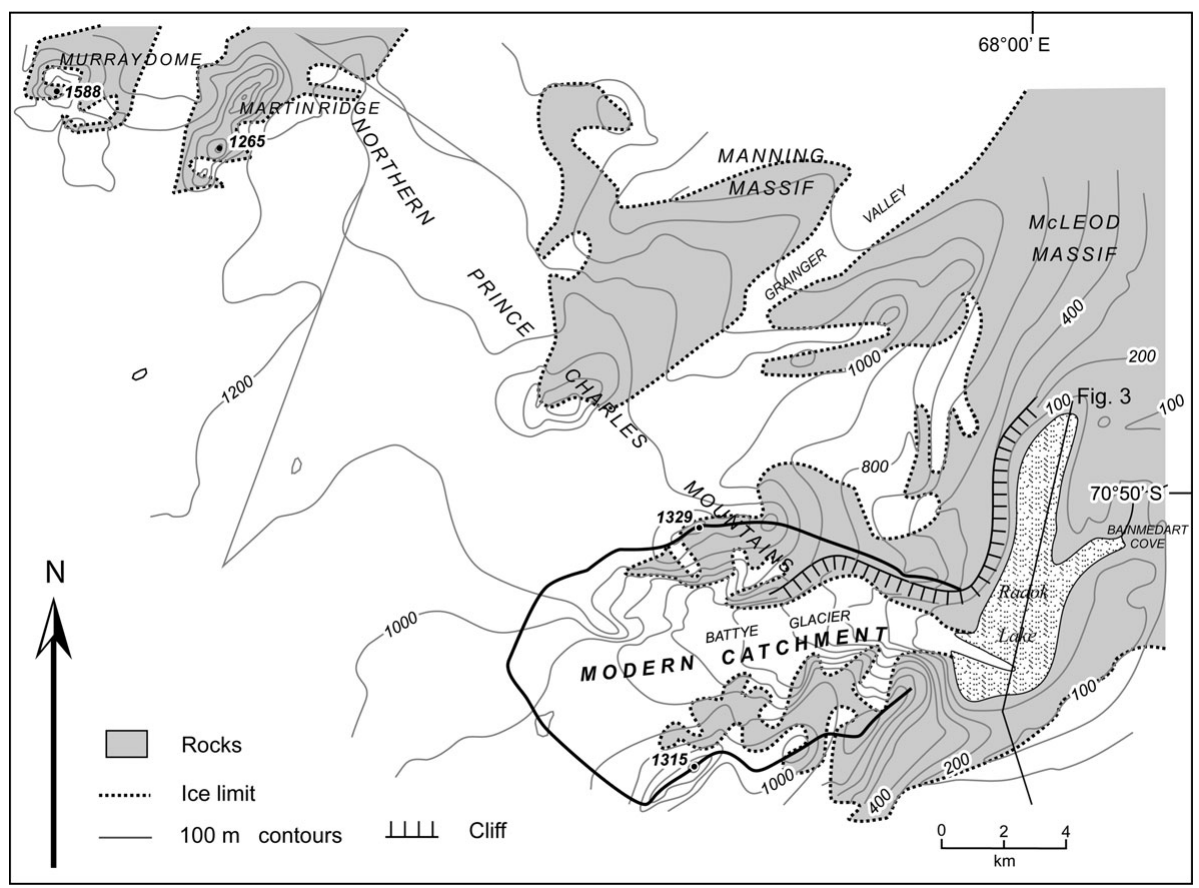

Fig. 2. Topographic map showing the Radok Lake basin and the modern boundary of the Battye Glacier catchment. 


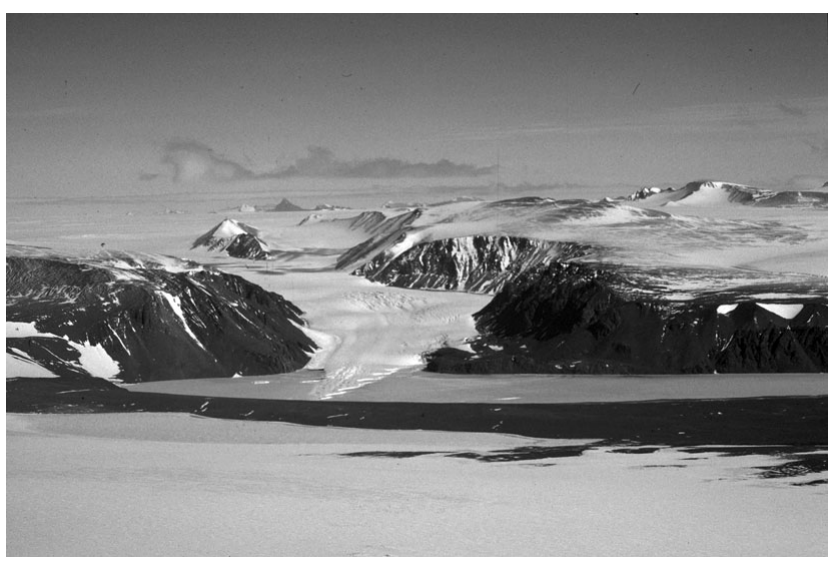

Fig. 4. Aerial photograph showing the Battye Glacier trough and Radok Lake basin.

\section{Carbonate sedimentology, isotopic composition, depositional age and environment}

The 5 to $10 \mathrm{~mm}$ thick, carbonate crusts were collected from the dissected channel section through the surface sediments. They outcrop along a defined stratum, with a
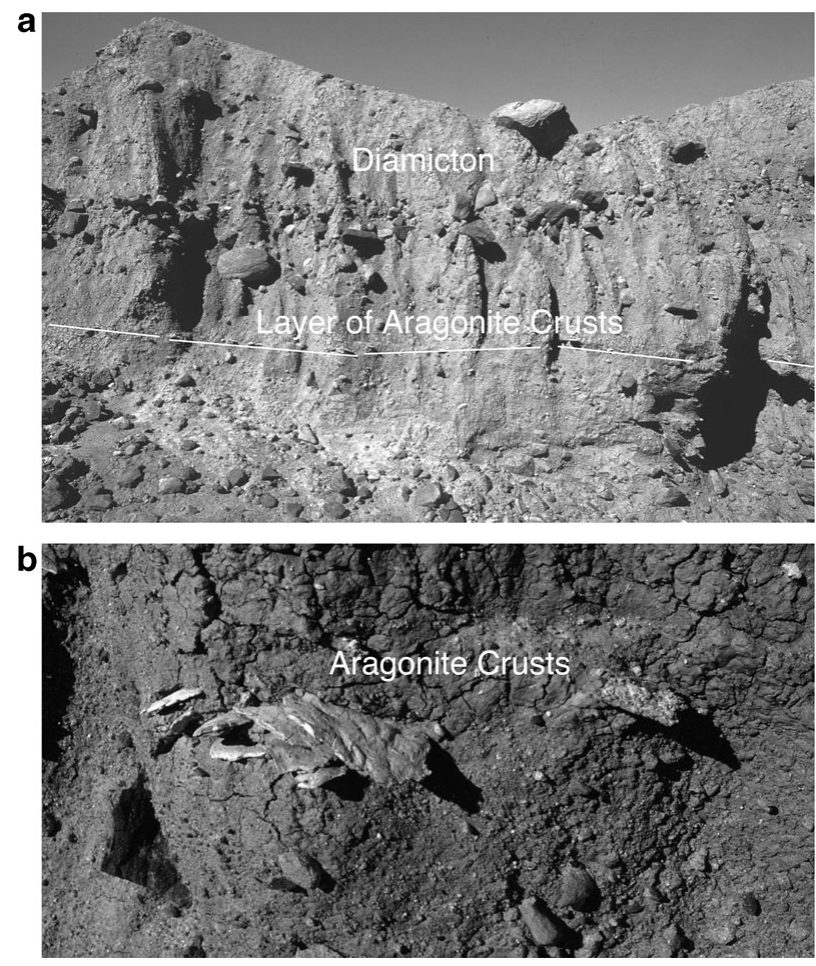

Fig. 5a. Photograph of vertical exposure cut by gullying in the thrust moraine sequence at $\sim 50 \mathrm{~m}$ elevation on the basin slope above the northern shoreline of modern Radok Lake. The exposure shows layer of aragonite crusts, outcropping beneath the diamicton. b. Close-up photograph showing a cluster of the discoid and draped aragonite crusts, outcropping in Fig. 5a. The stratigraphy and the whole preservation of the shallow water crusts, indicates in situ deposition at this location.

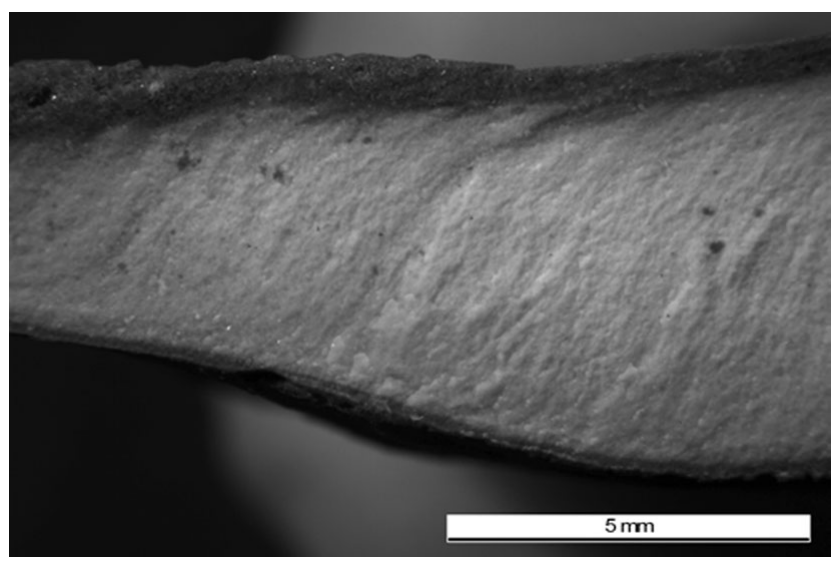

Fig. 6. Photomicograph of an aragonite crust section.

slight $\left(2^{\circ}\right)$ dip towards the modern lake shoreline (Fig. 5a). The discontinuous and discoid-shaped carbonate crusts, are typically $5-10 \mathrm{~cm}$ long, and occur as single layers or as clusters. (Figs $5 b$ \& 6). This layer forms a discontinuity and is overlain by $2-3 \mathrm{~m}$ of sediments comprising semistratified and massive basal diamicton, alternating with laminated silty sand. Downslope and to the west of the outcrop, Hambrey \& McKelvey (2000) reported the thrust moraine sequence, comprising discontinuous slabs of stratified glacio-lacustrine or fjordal sediments, with massive silty sand and laminated clayey silts, and silty sands, with dropstones. Hambrey \& McKelvey (2000) proposed that these sediments were distal turbidites, subglacial debris flows, and ice rafted deposits possibly of early Miocene to Pliocene-age Pagodroma Group that had been reworked by late Quaternary glacial events and deposited with preserved stratigraphy, in the ice marginal moraine, during ice retreat.

The carbonate crusts were analysed using X-Ray Diffraction (XRD) techniques and consist entirely of aragonite. The inorganic aragonite is micritic with thin laminae and some peloids, together with some algal filaments from microbial mats. Borings, and shell castings (gastropods) were present in a few samples. Low concentrations ( 0 to $10 \%$ ) of halite were measured by XRD on some samples of the surrounding silty sand sediments. The composition and structure of these aragonitic layers are similar to the Late Quaternary lake aragonites and algal limestones from the Taylor Valley, Transantarctic Mountains (Hendy 2000). Hence, the Radok Lake carbonate crusts are interpreted to have formed in association with algal mats in a shallow water environment.

Stable isotope mass spectrometry on six samples of aragonite (Table I) yielded a mean carbon isotopic composition $\delta^{13} \mathrm{C}_{\mathrm{PDB}}=1.59 \pm 0.28 \%$, and a mean oxygen isotope composition $\quad \delta^{18} \mathrm{O}_{\text {SMOW }}=-3.49 \pm 0.08 \%$. The calculated $\delta^{18} \mathrm{O}_{\mathrm{SMOW}}$ value of the parent water body from which the aragonites were precipitated under assumed 
Table I. Carbon and oxygen stable isotopic analyses of aragonites and snow/ice.

\begin{tabular}{|c|c|c|c|c|}
\hline Sample & $\begin{array}{c}\delta^{13} \mathrm{C}_{\mathrm{PDB}} \% \\
\text { aragonite }\end{array}$ & $\begin{array}{c}\delta^{18} \mathrm{O}_{\text {SMOW }} \% \\
\text { aragonite }\end{array}$ & $\begin{array}{c}\delta^{18} \mathrm{O}_{\text {SMOW }} \% \\
\text { meltwater }\end{array}$ & $\begin{array}{c}\delta^{18} \mathrm{O}_{\text {SMOW }} \% \\
\text { snow } / \text { ice }\end{array}$ \\
\hline Aragonite (mean $n=6$ ) & $1.59 \pm 0.28$ & $-3.49 \pm 0.08$ & & \\
\hline RadokLake@ 92 ka вр & & & -36.0 & \\
\hline Modern & & & $-28.4 \pm 0.3$ & \\
\hline Ice sheet snow@1100 to 2600 m & & & & -31 to -41 \\
\hline Modern Battye Glacier snow @ 1100 to 1300 m & & & & -25 to -31 \\
\hline
\end{tabular}

Note that all values are measured, except for the calculated $\delta^{18} \mathrm{O}_{\mathrm{SMOW}} \%$ value for Radok Lake meltwater at $52 \mathrm{ka}$ BP.

equilibrium conditions at $0^{\circ} \mathrm{C}$, is $-36 \%$ (after isotope fractionation effects are accounted for using the methods discussed in (Friedman \& O'Neill 1977). This is a reasonable assumption given that the modern lake water is isothermal varying by $0.90 \pm 0.07^{\circ} \mathrm{C}$ with depth (Bardin et al. 1990) and has a perennial ice cover. Any deviation to these conditions during aragonite precipitation would have required either the loss of the ice cover, or a negative water balance and transformation from freshwater to saline. The latter would cause an enrichment in the parent water and lower the freezing point of the water body, which would cause an greater fractionation for the aragonite $\delta^{18} \mathrm{O}$ composition (Friedman \& O'Neill 1977, Faure 1986). Both of these uncertainties would result in a more depleted $\delta^{18} \mathrm{O}$ composition of the original meltwater. Therefore, the significantly depleted $\delta^{18} \mathrm{O}$ composition of $-36 \%$ is considered a maximum value for the meltwater, and indicates that the parent water body formed a freshwater, lacustrine environment, and confirms the sedimentological interpretation for shallow water deposition.

The age of the aragonite precipitation was determined using multi-collector ICP-MS U-Th dating as $52.7 \pm$ $0.4 \mathrm{ka}$ BP (Table II). Solid samples of $\sim 1 \mathrm{mg}$ were cut from the upper- and basal-most $\sim 1 \mathrm{~mm}$ of the $\sim 7 \mathrm{~mm}$ aragonite layer using a dental drill after an initial sample of $11 \mathrm{mg}$ from the central part of the layer was found to be too large for efficient analysis due to a higher than expected U content of $52 \mathrm{ppm}$. The samples were cleaned in ultra pure water prior to dissolution by dropwise addition of concentrated nitric acid, and chemical separation and mass spectrometric analysis according to standard procedures described in Hellstrom (2003). Once corrected for the presence of initial ${ }^{230} \mathrm{Th}$ (using an assumed initial ${ }^{230} \mathrm{Th} /{ }^{232} \mathrm{Th}$ activity ratio of $0.75 \pm 0.75$ and fully propagating its uncertainty) the three samples reveal an age difference over the aragonite crust of between zero and $\sim 1000 \mathrm{yrs}$, indicating that deposition was concentrated in a narrow time window. The close agreement of the three analyses relative to their uncertainties confirms that the sample is unlikely to have been subject to post-depositional uranium mobility, and that their weighted mean can be considered a reliable absolute age determination. These age estimates confirm the stratigraphic integrity with the overlying, younger diamicton and laminites, since a paired ${ }^{10} \mathrm{Be}$ and ${ }^{26} \mathrm{Al}$ cosmogenic isotope age of $10.5 \pm 1 \mathrm{ka}$ was obtained for similar diamicton and laminite deposits located downslope from the channel exposure of the carbonates (Fink et al. 2006).

The $52.7 \pm 0.4 \mathrm{ka}$ BP age for the aragonites is coincident with the polar Warm Event A3 at $52 \mathrm{ka}$ BP that has been identified in both Antarctic and Greenland ice cores (Blunier \& Brook 2001). Whilst sedimentological evidence for the A3 event has not been reported in Antarctica, the Radok Lake aragonites represent a proxy for shallow water level at this time, and an indicator for water balance conditions. The location of the aragonite layers near the raised shoreline limit at $70 \mathrm{~m}$ elevation, together with their

Table II. U-Th isotopic analyses and age calculations for aragonite layer.

\begin{tabular}{|c|c|c|c|c|c|c|}
\hline Sample & {$\left[{ }^{230} \mathrm{Th} /{ }^{238} \mathrm{U}\right]^{\mathrm{a}}$} & {$\left[{ }^{234} \mathrm{U} /{ }^{238} \mathrm{U}\right]^{\mathrm{a}}$} & Raw age $(\mathrm{ka})^{\mathrm{b}}$ & {$\left[{ }^{232} \mathrm{Th} /{ }^{238} \mathrm{U}\right]$} & Corrected age $(\mathrm{ka})^{\mathrm{c}}$ & Corrected $\left[{ }^{234} \mathrm{U} /{ }^{238} \mathrm{U}\right]_{\mathrm{i}}^{\mathrm{d}}$ \\
\hline RL1-top & $0.464(02)$ & $1.192(3)$ & $52.9(0.3)$ & $0.00117(01)$ & $52.8(0.4)$ & $1.223(3)$ \\
\hline RL1-mid & $0.458(10)$ & $1.192(3)$ & $51.9(1.4)$ & $0.00032(01)$ & $51.9(1.5)$ & $1.223(4)$ \\
\hline RL1-bas & $0.475(03)$ & $1.196(3)$ & $54.1(0.4)$ & $0.03233(41)$ & $52.0(2.1)$ & $1.227(4)$ \\
\hline
\end{tabular}

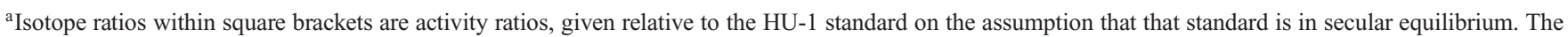
MC-ICP-MS analytical procedure used is described in detail in Hellstrom (2003). Figures in brackets are external $95 \%$ uncertainties in the last digit(s).

${ }^{b}$ Uncorrected U-Th ages are calculated using the conventional ${ }^{238} \mathrm{U}-{ }^{234} \mathrm{U}-{ }^{230} \mathrm{Th}$ disequilibrium age equation, with the decay constants $\lambda_{234}=2.835 \times 10^{-6}$ and $\lambda_{230}=9.195 \times 10^{-6}$ (uncertainty in the decay constants has not been propagated).

${ }^{\mathrm{c}}$ Corrected $\mathrm{U}-\mathrm{Th}$ ages are calculated assuming that $\left[{ }^{230} \mathrm{Th} /{ }^{232} \mathrm{Th}\right]$ at time of formation was $0.75 \pm 0.75$, the uncertainty in this activity ratio being propagated into the $95 \%$ age uncertainties given. The uncertainty-weighted mean of the three analyses is $52.7 \pm 0.4 \mathrm{ka}$.

${ }^{\mathrm{d}}$ Calculated $\left[{ }^{234} \mathrm{U} /{ }^{238} \mathrm{U}\right]$ at time of sample formation, on the basis of measured $\left[{ }^{234} \mathrm{U} /{ }^{238} \mathrm{U}\right]$ and the corrected age.

${ }^{\text {e}}$ The initial analysis of the middle section of the layer was found to have a very much greater $U$ content (51 $\left.500 \mathrm{ng} \mathrm{g}^{-1}\right)$ than anticipated and hence has a large analytical uncertainty in $\left[{ }^{230} \mathrm{Th} /{ }^{238} \mathrm{U}\right]$. 
preservation as discoid lenses and outcropping along a defined stratigraphic boundary conforming with the basin slope, probably indicates in situ deposition with later deposition of the overlying diamicton during an isotope Stage 2 glacial advance (Fig. 5a \& b). Despite any uncertainty in the provenance (in situ or transported from lower elevation by the glacial readvance) the aragonite isotopic composition can be used to investigate the meltwater evolution in Radok Lake.

\section{Radok Lake hydrology and aragonite precipitation}

The modern Radok Lake is isothermal, well mixed and has a uniform $\delta^{18} \mathrm{O}_{\text {SMOW }}$ composition of $-28.4 \pm 0.3 \%$ (Wand et al. 1988), some $8 \%$ more enriched than the parent water body from which the aragonite crusts had precipitated. Meltwater inflow from ice draining the Battye Glacier catchment (shown in Fig. 2) is the primary source of water entering modern Radok Lake. The Battye Glacier is flowing in a deep structural valley with an ice thickness of approximately $200-300 \mathrm{~m}$, basal temperatures close to melting and sliding on its base. The glacier is draining the ice plateau to the south of the Aramis Range. The present water equivalent snow accumulation rates at $1000 \mathrm{~m}$ elevation are $50-75 \mathrm{~kg} \mathrm{~m}^{2} \mathrm{a}^{-1}$. Meltwater is principally contributed from ice surface ablation and basal melting of the glacier and its floating glacier tongue. Meltwater also flows in well established gullies from the McLeod Massif to the north of the lake and into Bainmedart Cove. Summer meltwater draining from these sources is derived from local precipitation in the form of snow. The modern $\delta^{18} \mathrm{O}_{\text {SMOW }}$ composition of Radok Lake water is equivalent to the mean $\delta^{18} \mathrm{O}_{\text {SMOW }}$ composition of surface snows in the modern accumulation zone of Battye Glacier catchment (750-1000 $\mathrm{m}$ elevation), which have a range of -25 to $-31 \%$. The modern Radok Lake basin holds $2.7 \times 10^{6}$ mega litres and, we estimate that annual meltwater inflow is between 2.5 to $3.0 \times 10^{3}$ mega litres if the Battye Glacier is in mass balance. Some annual water loss occurs through evaporation and outflow draining over the shallow sill into Pagodroma Gorge, during summer. The perennial winter lake ice cover is partially melted around the margins during summer forming a moat, which allows the water to be mixed by currents generated by surface winds. Since the lake is well mixed it is estimated that residence time in the lake is $\sim 1000 \mathrm{yrs}$, based on the lake volume and inflow estimates. It is also estimated that Holocene meltwater inflow rates to Radok Lake are significantly larger than those during the glacial periods when snow accumulation rates in coastal East Antarctica were less than half the Holocene rates (Morgan et al. 1997). It is also suggested that much smaller alpine glaciers existed during the last glacial-age, since the morphological evidence defines a Holocene alpine glacial expansion due to increased accumulation and warmer temperatures Mabin (1992).
The chemical precipitation of aragonite requires the parent water to be saturated in $\mathrm{CaCO}_{3}$. The $\mathrm{pH}$, mean $\mathrm{Ca}$ and $\mathrm{HCO}_{3}$ composition of water in modern Radok Lake is $7.88 \pm 0.13$, $0.47 \pm 0.20 \mathrm{mg} \mathrm{l}^{-1}$ and $0.88 \pm 0.2 \mathrm{mg} \mathrm{l}^{-1}$, respectively (Wand et al. 1988, Bardin et al. 1990). The total ion content is between 100 to $150 \mathrm{mg} \mathrm{l}^{-1}$ (Bardin et al. 1990). Although $\mathrm{Ca}$ and $\mathrm{HCO}_{3}$ comprise $40 \%$ of the total ionic content in modern Radok Lake, the water is undersaturated with respect to aragonite. In comparison, Taylor Valley (McMurdo Region, East Antarctica) lacustrine aragonites and algal limestones precipitated in shallow water environments, where the water was depleted in $\mathrm{CO}_{2}$ by algal photosynthesis, leading to an enrichment in $\delta^{13} \mathrm{C}$ (Hendy et al. 1979, Hendy 2000). The enriched mean carbon isotopic composition $\delta^{13} \mathrm{C}_{\mathrm{PDB}} 1.59 \pm 0.28 \%$ and inclusion of algal filaments in the Radok Lake aragonites, indicates enrichment by photosynthesis combined with slight evaporative conditions. Such conditions would have enhanced the $\mathrm{CaCO}_{3}$ saturation of the shallow, nearshore, lake water resulting in aragonite precipitation. These are typical environmental conditions for aragonite precipitation in arid environments (Tucker \& Wright 1990). Whilst the exact nature of the lake nearshore environment during aragonite precipitation is speculative, there is little doubt that the isotopic composition of the aragonites reflects that of the parent, ancestral Radok Lake water at $\sim 53 \mathrm{ka} \mathrm{BP.}$

\section{Radok Lake meltwater sources during stage 3 and implications for glacial history}

A statistically robust relationship between $\delta^{18} \mathrm{O}$, surface air temperature and ice sheet elevation exists for Antarctica (Zwally et al. 1998). Accordingly, a relationship between $\delta^{18} \mathrm{O}$ in modern surface snows and elevation for the ice sheet to the west of the northern Prince Charles Mountains is shown in Fig. 7 (Goodwin 1995, Higham \& Craven 1997). During Isotope Stage 3 (50 ka BP), the $\delta^{18} \mathrm{O}_{\mathrm{SMOW}}$ composition of surface snow is known from East Antarctic ice core analyses to be more depleted by $-4 \%$ than the present (for Vostok (Jouzel et al. 1987), Dome C (EPICA 2004) and Law Dome (Morgan et al. 1997). This includes the changes due to cooler air temperature and increased continentality. The $\delta^{18} \mathrm{O}$-elevation relationship for Isotope Stage 3 (Fig. 6) indicates that glacial meltwater with a mean $\delta^{18} \mathrm{O}_{\text {SMOW }}$ composition of $-36 \%$ would have originated from an ice sheet elevation range of 1350 to $1700 \mathrm{~m}$.

\section{Battye Glacier meltwater}

The primary candidate for the Stage 3 meltwater source is the alpine Battye Glacier itself. Assuming no change to the Holocene catchment boundaries for Battye Glacier during Stage 3, the range of meltwater $\delta^{18} \mathrm{O}$ would be -29 to $-35 \%$, which is more enriched than the aragonite-based 


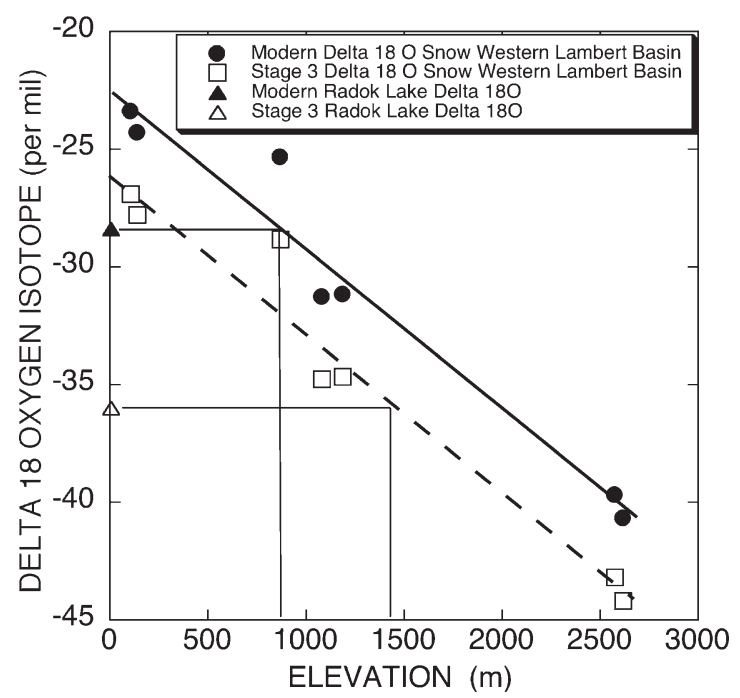

Fig. 7. Diagram showing the relationship between $\delta^{18} \mathrm{O}$ in modern surface snows and elevation for the ice sheet to the west of the northern Prince Charles Mountains. The $\delta^{18} \mathrm{O}$ in modern surface snow data is taken from Goodwin (unpublished data) and Higham \& Craven (1997). The $\delta^{18} \mathrm{O}$ composition of the modern Radok Lake is from Bardin et al. (1990). Also shown is the relationship between $\delta^{18} \mathrm{O}$ in isotope stage 3 surface snows and elevation for the ice sheet to the west of the northern Prince Charles Mountains, together with the calculated $\delta^{18} \mathrm{O}$ composition of Radok Lake.

meltwater values. The modern topographic ridge at 1100 to $1300 \mathrm{~m}$ which constrains an expansion of the Battye Glacier catchment to south of Murray Dome and Martin Ridge in the southern Amery Peaks and to Manning Massif in the east (Fig. 2). Any expansion of ice further to the west during Stage 3 would have resulted in ice drainage to the north of the Aramis Range along the Charybdis Glacier, and to the south along the ice stream adjacent to Mount Meredith, and downstream into the main Lambert Glacier system. Therefore, these topographic constraints, together with significantly lower than Holocene, snow accumulation rates during Stage 3, preclude an expanded Battye Glacier catchment as the sole source of Radok Lake meltwater during Stage 3. In addition, there is also no morphological evidence to support an expanded ice dome south of Murray Dome and Martin Ridge in the southern Amery Peaks and to Manning Massif in the east (Adamson et al. 1997, M. Mabin, personal communication 2000).

\section{Lambert Glacier western tributary meltwater sources}

An alternative explanation for the contribution of a meltwater source with a depleted $\delta^{18} \mathrm{O}$ composition is that marginal ice of the Lambert Glacier expanded into Radok Lake during Stage 3. For the water level in Radok Lake to be 50-70 m higher during Stage 3, an ice dam across Bainmedart Cove would be required, since the modern lake level is

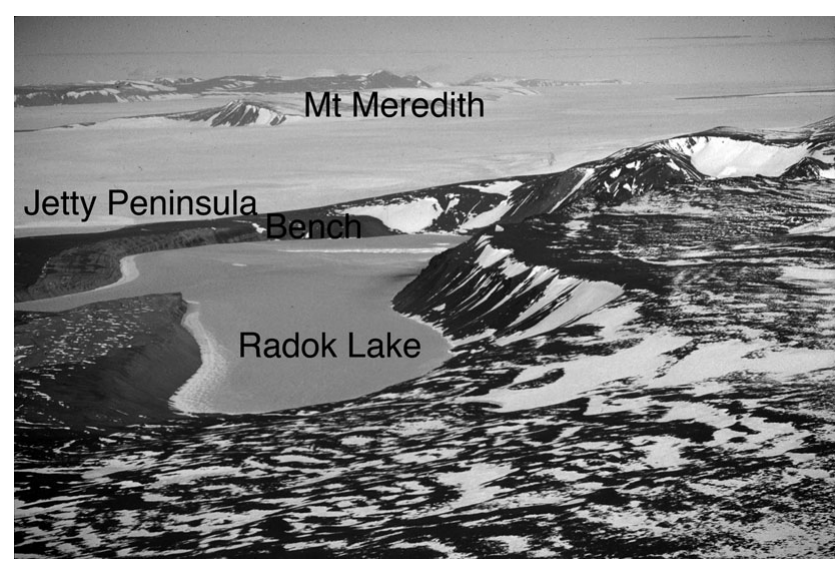

Fig. 8. Oblique aerial photograph looking south across Radok Lake, the bedrock bench, Jetty Peninsula ice ridge, and Mount Meredith.

controlled by a structural sill in Bainmedart Cove which is at $7 \mathrm{~m}$ elevation. There are two possibilities for the source of the ice dam: an expanded Battye Glacier tongue; and, a marginal expansion of the Lambert Glacier. The main Lambert Glacier/Amery Ice Shelf system is currently separated from Radok Lake by a grounded ice ridge up to $300 \mathrm{~m}$ elevation, known as Jetty Peninsula (Fig. 8). The morphology and orientation of the Jetty Peninsula indicates that it is the downstream extension of ice draining from the western Lambert Glacier basin slopes, via small, outlet ice streams flowing between the Battye Glacier catchment and Mount Meredith and Fisher Massif to the south. Between the ice ridge and Radok Lake is a $200 \mathrm{~m}$ wide ice striated bench at $100 \mathrm{~m}$ elevation, that extends north-east to Flagstone Bench. The bench comprises Amery Group sediments, and the overlying Miocene-Pliocene Pagodroma glacial sediments have been eroded away by glacial readvances of the Lambert Glacier margins (Fink et al. 2006). These authors reported a paired ${ }^{10} \mathrm{Be}$ and ${ }^{26} \mathrm{Al}$ cosmogenic isotope age of $15 \pm 1 \mathrm{ka}$ for ice retreat from the surface of the bench at $125 \mathrm{~m}$ elevation, although it is unclear whether Battye Glacier ice or Lambert Glacier ice occupied the site.

The modern ice column of the Amery Ice Shelf and Lower Lambert Glacier has a mean $\delta^{18} \mathrm{O}_{\text {SMOW }}$ composition of $-38 \%$ (Morgan 1972), which corresponds to the mean composition of ice draining from elevations of 1500 to $3000 \mathrm{~m}$ elevation in the interior of the Lambert Glacier basin. It is likely that the Lambert Glacier drainage pattern in the interior of the basin during Isotope Stage 3, was similar to the present pattern since ice sheet elevation changes were small in central east Antarctica (Jouzel et al. 1987). Therefore, during Isotope Stage 3, Lambert Glacier ice draining from the western basin through the Mount Meredith and Fisher Massif Ice Streams to the Amery Embayment would have had a mean $\delta^{18} \mathrm{O}_{\text {SMOW }}$ composition of $\sim-42 \%$ (including the $-4 \%$ offset). Thus, 
the western Lambert Glacier ice is a candidate for the depleted meltwater $\delta^{18} \mathrm{O}$ during Stage 3 .

However, an expansion of these ice streams, requires either a significant increase in snow accumulation rates during Isotope Stage 1 to 3 (which is not supported by the deep ice core records), or thickening and grounding of the Amery Ice Shelf and Lower Lambert Glacier, in the vicinity of the Amery Oasis. The modern Jetty Peninsula ice ridge margin is within $1 \mathrm{~km}$ of the southern edge of the Radok Lake basin, and approximately $100 \mathrm{~m}$ above the present lake surface elevation. The modern ice draft of the Lower Lambert Glacier in this region is approximately $100 \pm 50 \mathrm{~m}$ for some $10 \mathrm{~km}$ across the glacier, and then the ice draft decreases to 700-800 m (Fricker et al. 2002, and unpublished ice thickness and bathymetry data, Antarctic Climate and Ecosystems Cooperative Research Centre, Hobart, Australia). Therefore, grounding of the lateral margins of the Lower Lambert Glacier would have been forced by the global sea level lowering of between 60 $80 \mathrm{~m}$ at 50 to $60 \mathrm{ka}$ BP (Thompson \& Goldstein 2006). The grounding of the Lower Lambert Glacier ice stream in the vicinity of Jetty Peninsula would have caused a thickening of the upstream ice sheet profile and result in a marginal glacial expansion across the bedrock ridge, and the discharge of ice into Radok Lake.

\section{Conclusions}

The sedimentology and isotope geochemistry of the aragonite crusts constrains their depositional environment to shallow water lacustrine during the Stage 3 warm event A3. At this time, Radok Lake meltwater was significantly more isotopically depleted than at present. The only plausible explanation for the isotopic depletion is that ancestral Radok Lake was receiving meltwater from both the expanded Battye Glacier tongue and an advance of the western Lambert Glacier. Previous papers have indicated that there is unequivocal evidence for Late Quaternary ice flowing from the Mount Meredith area over the flat bedrock bench at $\sim 100 \mathrm{~m}$ elevation along the southern edge of Radok Lake, which extends north to the south-east rim of Beaver Lake and flanks Jetty Peninsula (Adamson et al. 1997, Fink et al. 2006). Jetty Peninsula is a $300 \mathrm{~m}$ high, lateral ice ridge separating the Amery Oasis from the Amery Ice Shelf. The new results on Stage 3 meltwater evolution in Radok Lake suggest that grounded ice from the western Lambert Glacier-Amery Ice Shelf system has thickened by at least $100 \mathrm{~m}$ adjacent to Jetty Peninsula and the Amery Oasis, during Stages 3 and 4 of the Last Glacial cycle. The Radok Lake aragonites indicate that lake level may have been $70 \mathrm{~m}$ higher than present during the A3 warm event. The elevated lake level may have been due to a more positive water balance or to the ice advance damming the outlet in Bainmedart Cove. Subsequently, during Stage 2 of the Last Glacial Cycle, a glacial expansion in the Radok Lake basin occurred, as recorded by the emplacement of glacial diamicton, and associated thrust moraine sediments over the prior shoreline. This glacial history provides important boundary conditions for constraining grounded ice reconstructions of the last glacial Lambert Glacier-Amery Ice Shelf system, to at least the Amery Oasis region.

\section{Acknowledgements}

The fieldwork was conducted during the 1989-90 Australian National Antarctic Research Expeditions (ANARE). The author acknowledges the logistical support of ANARE and the use of laboratory facilities of the Glaciology Program, Australian Antarctic Division. Mr Olivier Rey-Lescure drafted the maps. Mr Ben Galton-Fenzi, Antarctic Climate and Ecosystems Cooperative Research Center, Hobart, Australia, provided the ice draft data for the Lower Lambert Glacier. The authors' acknowledge the constructive comments of two reviews by Drs Berry Lyons and Brenda Hall that substantially improved the paper. Dr David Fink, Australian Nuclear Science and Technology Organisation (ANSTO) provided funding for the $\mathrm{U}-\mathrm{Th}$ dating analyses.

\section{References}

Adamson, D.A., Mabin, M.C.G. \& Luly, J.G. 1997. Holocene isostasy and late Cenozoic development of landforms including Beaver and Radok Lake basins in the Amery Oasis, Prince Charles Mountains, Antarctica. Antarctic Science, 9, 299-306.

Bardin, V.I., Piskun, A.A. \& Shmidberg, N.A. 1990. Hydrological and hydrochemical characteristics of deep water basins in Prince Charles Mountains. Antarktika doklady komissii, No. 29, 97-112. [In Russian with English summary].

Blunier, T. \& Brook, E.J. 2001. Timing of millennial-scale climate change in Antarctica and Greenland during the last glacial period. Science, 291, 109-112.

EPICA. 2004. Eight glacial cycles from an Antarctic ice core. Nature, 429, $623-628$.

Faure, G. 1986. Principles of isotope geology, 2nd ed. New York: John Wiley and Sons, 589 pp.

Fink, D., McKelvey, B.C., Hambrey, M.J., Fabel, D. \& Brown, R. 2006. Pleistocene deglaciation chronology of the Amery Oasis and Radok Lake, northern Prince Charles Mountains, Antarctica. Earth and Planetary Science Letters, 243, 229-243.

Fricker, H.A., Allison, I., Craven, M., Hyland, G., Ruddell, A., Young, N., Coleman, R., King, M., Krebs, K. \& Popov, S. 2002. Redefinition of the Amery Ice Shelf, East Antarctica, grounding zone. Journal of Geophysical Research, 107, 10.1029/2001JB000383.

Friedman, I. \& O’Neill, J.R. 1977. Compilation of stable isotope fractionation factors of geochemical interest. In Fleisher, M. Data of geochemistry, 6th ed. Washington: US Geological Survey Professional Paper No 440-E, 12 pp.

Goodwin, I.D. 1995. On the Antarctic contribution to Holocene sea level. $\mathrm{PhD}$ thesis, Institute of Antarctic and Southern Ocean Studies, University of Tasmania, $315 \mathrm{pp}$. [Unpublished].

Hambrey, M.J. \& McKelvey, B. 2000. Neogene fjordal sedimentation on the western margin of the Lambert Graben, East Antarctica. Sedimentology, 47, 577-607. 
Hellstrom, J. 2003. Rapid and accurate U/Th dating using parallel ioncounting multi-collector ICP-MS. Journal of Analytical Atomic Spectrometry, 18, 1346-1351.

Hendy, C.H., Healy, T.R., Ryner, E.M., Shaw, J. \& Wilson, A.T. 1979. Late Pleistocene glacial chronology of the Taylor Valley, Antarctica, and the global climate. Quaternary Research, 11, 172-184.

Hendy, C.H. 2000. Late Quaternary lakes in the McMurdo Sound region of Antarctica. Geografiska Annaler, 82A, 411-432.

Higham, M. \& Craven, M. 1997. Surface mass balance and snow surface properties from the Lambert Glacier Basin traverses, 1990-1994. Antarctic CRC Research Report, 9, 129 pp.

Jouzel, J., Lorius, C., Petit, J.R., Genthon, C., Barkov, N.I., Kotlyakov, V.M. \& Petrov, V.M. 1987. Vostok ice core: a continuous isotope temperature record over the last climatic cycle (160,000 years). Nature 329, 403-408.

Mabin, M.C.G. 1992. Late Quaternary ice-surface fluctuations of the Lambert Glacier. In Yoshida, Y. et al., eds. Recent Progress in Antarctic Earth Sciences, Tokyo: Terrapub, 683-687.

McKelvey, B.C., Hambrey, M.J., Mabin, M.C.G., Harwood, D.M. \& Webb, P.N. 1995. The Neogene Pagodroma Group in the northern Prince Charles Mountains, East Antarctica. Abstracts of the VII International Symposium on Antarctic Earth Sciences, Siena Italy, 262 pp.
McKelvey, B.C., Hambrey, M.J., Harwood, D.M., Mabin, M.C.G., Webb, P.-N. \& Whitehead, J.M. 2001. The Pagodroma Group: a Cenozoic record of the East Antarctic ice sheet in the northern Prince Charles Mountains. Antarctic Science, 13, 455-468.

Morgan, V.I. 1972. Oxygen isotope evidence for bottom freezing on the Amery Ice Shelf. Nature, 238, 393-394.

Morgan, V.I., Wookey, C.W., Li, J., Van Ommen, T.D., Skinner, W. \& FitzPatrick, M.F. 1997. Site information and initial results from deep drilling on Law Dome, Antarctica. Journal of Glaciology, 43, $3-10$.

Thompson, W.G. \& Goldstein, S.L. 2006. A radiometric calibration of the SPECMAP timescale. Quaternary Science Reviews, 25, 3207-3215.

Tucker, M.E. \& Wright, V.P. 1990. Carbonate sedimentology. Oxford: Blackwell Scientific Publications, 482 pp.

Wand, U., Hermichen, W.D. \& Hobling, R. 1988. Stable isotope and hydrochemical studies of Beaver Lake and Radok Lake, MacRobertson Land, East Antarctica. Zfi Mitteilungen, 143, 99-111.

Zwally, H.J., Giovinetto, M., Craven, M., Morgan, V. \& Goodwin, I. 1998. Areal distribution of the oxygen-isotope ratio in Antarctica: comparison of results based on field and remotely sensed data. Annals of Glaciology, 27, $583-590$. 